\title{
The action of a synthetic pentasaccharide on thrombin generation in whole plasma
}

Citation for published version (APA):

Beguin, S., Choay, J., \& Hemker, H. C. (1989). The action of a synthetic pentasaccharide on thrombin generation in whole plasma. Thrombosis and Haemostasis, 61(3), 397-401. https://doi.org/10.1055/s0038-1646603

Document status and date:

Published: 01/01/1989

DOI:

10.1055/s-0038-1646603

Document Version:

Publisher's PDF, also known as Version of record

\section{Please check the document version of this publication:}

- A submitted manuscript is the version of the article upon submission and before peer-review. There can be important differences between the submitted version and the official published version of record.

People interested in the research are advised to contact the author for the final version of the publication, or visit the DOI to the publisher's website.

- The final author version and the galley proof are versions of the publication after peer review.

- The final published version features the final layout of the paper including the volume, issue and page numbers.

Link to publication

\footnotetext{
General rights rights.

- You may freely distribute the URL identifying the publication in the public portal. please follow below link for the End User Agreement:

www.umlib.nl/taverne-license

Take down policy

If you believe that this document breaches copyright please contact us at:

repository@maastrichtuniversity.nl

providing details and we will investigate your claim.
}

Copyright and moral rights for the publications made accessible in the public portal are retained by the authors and/or other copyright owners and it is a condition of accessing publications that users recognise and abide by the legal requirements associated with these

- Users may download and print one copy of any publication from the public portal for the purpose of private study or research.

- You may not further distribute the material or use it for any profit-making activity or commercial gain

If the publication is distributed under the terms of Article $25 \mathrm{fa}$ of the Dutch Copyright Act, indicated by the "Taverne" license above, 


\title{
The Action of a Synthetic Pentasaccharide on Thrombin Generation in Whole Plasma
}

\author{
S. Béguin, J. Choay*, and H. C. Hemker \\ From the Department of Biochemistry, University of Limburg, Maastricht, \\ The Netherlands and Institut Choay*, Paris, France
}

\begin{abstract}
Key words
Heparin - Pentasaccharide - Thrombin generation - Factor $\mathrm{X}_{\mathrm{a}}$
\end{abstract}

\section{Summary}

We investigated the effect on thrombin generation in plasma of the pentasaccharide that represent the AT III/binding site in heparin. This compound has no effect on the breakdown of thrombin in plasma. It dose-dependently inhibits the formation of thrombin in both the intrinsic and the extrinsic pathway. If coagulation is triggered by the complete prothrombinase complex (phospholipid - factor $\mathrm{V}_{\mathrm{a}}$ - factor $\mathrm{X}_{\mathrm{a}}$ ) under conditions in which the large majority of factor $\mathrm{X}_{\mathrm{a}}$ is bound to the complex, the inhibition of prothrombinase activity is only minor. If no factor $\mathrm{V}_{\mathrm{a}}$ is present or if the prothrombinase activity is triggered by adding complete tenase (PL-FVIII $-\mathrm{FIX}_{\mathrm{a}}$ ) or incomplete tenase (PL-FIX ${ }_{a}$ ) to the plasma the inhibition by pentasaccharide is of the same magnitude as that in the intrinsic or extrinsic system.

We conclude that the pentasaccharide inhibits blood coagulation by katalysing the inactivation of free factor $\mathrm{X}_{\mathrm{a}}$. In contrast to classical heparin it does inhibit the peak of thrombin formation in platelet rich plasma, probably because it is less subject to inactivation by heparin binding proteins from platelets than classical heparin is.

\section{Introduction}

From data obtained with purified factors $\mathrm{II}_{\mathrm{a}}$ and $\mathrm{X}_{\mathrm{a}}$ added to whole plasma it has been well documented that, with decreasing molecular mass, heparin species gradually loose their ability to act as a catalyst for antithrombin III dependent thrombin inactivation but maintain an activity in factor $\mathrm{X}_{\mathrm{a}}$ inactivation (1-5). The synthetic pentasaccharide prepared by Choay et al. $(6,7)$ that represents the AT III binding site of heparin carries this tendency to an extreme in that it has no activity in the AT III-thrombin interaction but has a persistent high anti-factor $\mathrm{X}_{\mathrm{a}}$ activity (7).

Recently we developed a method to study the generation of prothrombinase activity in plasma triggered via the extrinsic and intrinsic pathways (8). We observed that the influence of standard unfractionated heparin on the inactivation of thrombin and factor $\mathrm{X}_{\mathrm{a}}$ generated endogenously in plasma differs considerably from its action on purified factors added to plasma. The inactivation of endogenously generated factor $\mathrm{X}_{\mathrm{a}}$ active in prothrombinase was shown to be not or hardly enhanced by unfractionated heparin $(9,10)$.

It follows that the mode of action of any heparin on activated clotting factors generated in plasma cannot be foreseen from studies carried out on purified factors. This prompted us to

Correspondence to: Dr. S. Béguin, Department of Biochemistry, University of Limburg, P.O. Box 616, 6200 MD Maastricht, The Netherlands investigate the mode of action of the synthetic pentasaccharide in plasma with our methods.

In platelet rich plasma the action of a heparin is even less predictable than in platelet poor plasma. At concentrations of up to $0.4 \mathrm{U} / \mathrm{ml}$ unfractionated heparin will not or hardly decrease the peak amount of thrombin formed; it will only retard the appearance of the thrombin peak $(9,11)$. This lack of inhibition can be attributed to neutralization of the heparin by platelet factor 4 that is released from the platelets as soon as they are activated by thrombin formed in the plasma. The increase of the lagtime of thrombin formation is due to the fact that, in the presence of heparin, inhibition occurs of the small amounts of thrombin that form during the lagphase and that are responsible for the triggering of the platelets $(9,11)$. Again, it seemed worthwile to investigate what the behaviour of pentasaccharide would be in this setup.

Part of the results given in this article has been presented as a plenary lecture at the XIth I.S.T.H. Congress (Brussels, 1987) (9).

\section{Materials and Methods}

All chemicals were of the highest grade commercially available.

Reptilase was obtained from Laboratoires Stago (Asnières, France), the solution was prepared according to the instructions of the manufacturer.

Soybean trypsin inhibitor (batch No. 43 F-800) was obtained from Sigma (St. Louis, USA). A $10 \mathrm{mg} / \mathrm{ml}$ solution in buffer A was used.

Staphylocoagulase was prepared as described by Hendrix et al. (12) or obtained from Laboratoires Stago (Asnières, France) and prepared according to the indications of the manufacturer.

Chromogenic substrate for thrombin was H.D-Phe-Pip-Arg-pNA. $2 \mathrm{HCl}$ (\$2238) from KABI, Sweden.

The phospholipid vesicle preparation contained $20 \%$ phosphatidylserine and $80 \%$ phosphatidylcholine and was prepared according to Rosing et al. (13). Kaolin was "Kaolin léger" provided by B.L.B. Laboratoires du Bois de Boulogne (Puteaux, France). Thromboplastin was prepared according to Owren and Aas (14).

Buffers: A - 0.05 M Tris- $\mathrm{HCl}, 0.1 \mathrm{M} \mathrm{NaCl}$ pH 7.35, with $0.5 \%$ ovalbumin (Sigma); B - Buffer A with 20 mM EDTA pH 7.9.

The 4th International Standard Heparin was supplied by Dr. T. W. Barrowcliffe and Pentasaccharide by the Choay Institute (15). The mean molecular weight of the heparin was given as 14,000 and its specific activity was $194 \mathrm{U} / \mathrm{mg}$. It is assumed to contain $\sim 30 \%$ of high affinity material, so that $1 \mathrm{U}$ represents approximately $1.5 \mu \mathrm{g}$ of high affinity heparin or $0.1 \mathrm{nMole}$. The pentasaccharide has a M. W. of 1,714 .

Blood from healthy donors was collected on $0.13 \mathrm{M}$ trisodium citrate; nine parts of blood to one part of citrate solution. A first and a second centrifugation were performed at $900 \times \mathrm{g}$, at $15^{\circ} \mathrm{C}$ for $15 \mathrm{~min}$. A third centrifugation was done at $4^{\circ} \mathrm{C}$, for 1 hour at $23,000 \times \mathrm{g}$. The platelet free plasma thus obtained was stored at $-80^{\circ} \mathrm{C}$. It was checked that the clotting factors and the antiproteases were in the normal range. This plasma is referred to as (platelet free) normal plasma in the text.

Defibrinated plasma was obtained by mixing an aliquot of plasma with 1:50 volume of a reptilase solution, letting a clot form for $10 \mathrm{~min}$ at $37^{\circ} \mathrm{C}$ and keeping the clotted plasma at $0^{\circ} \mathrm{C}$ for $10 \mathrm{~min}$. The fibrin formed was discarded by centrifugation $\left(10 \mathrm{~min}, 5,000 \times \mathrm{g}, 4^{\circ} \mathrm{C}\right)$ or by winding it on a small plastic spatula. The concentrations of factors II, V, VII, VIII, IX, 
$\mathrm{X}, \mathrm{XI}$, and XII did not significantly change by the reptilase treatment as has been shown before (8).

Platelet rich plasma was obtained by centrifugation $(200 \times \mathrm{g}, 15 \mathrm{~min})$ of freshly drawn citrated blood from a fasting donor. The platelet count was adjusted to $3.0 \times 10^{8} / \mathrm{ml}$ with homologous platelet poor plasma (centrifuged for $15 \mathrm{~min}$ at $10,000 \times \mathrm{g}$ ). Plastic tubes and pipettes were used throughout so as to minimize contact activation.

Human brain thromboplastin was prepared as described in Owren and Aas (14). It was homogenized in a Potter Elvehjem homogeniser for $3 \mathrm{~min}$, centrifugated at $2,000 \times \mathrm{g}$ for $15 \mathrm{~min}$ and stored at $-20^{\circ} \mathrm{C}$ in $0.1 \mathrm{ml}$ aliquots. Before use it was thawed, diluted with $0.05 \mathrm{M}$ Tris- $\mathrm{HCl}$ pH 7.35 containing $100 \mathrm{mM}$ of $\mathrm{CaCl}_{2}$, so as to obtain a clotting time of $90 \mathrm{sec}$ when incubated with normal non defibrinated plasma under the same conditions as used for the thrombin generation experiments. The dilution required was $1: 40$ for the batch of thromboplastin used here and between $1: 30$ and 1:50 with other batches. The diluted thromboplastin was incubated at $37^{\circ} \mathrm{C}$ for 1 hour and then kept at room temperature. In this way it remained stable for at least 4 hours. In an independent study (16), we showed that at this concentration of thromboplastin, the reinforcement loop via factor VII dependent activation of factor IX does not play a significant role: prothrombinase activities in the absence and in the presence of factor IX were similar.

Purified proteins: Human $\alpha$-thrombin was prepared according to Pletcher et al. (17), active site titrated and used for establishing a standard curve. Factors $\mathrm{V}, \mathrm{V}_{\mathrm{a}}$ and factor $\mathrm{X}_{\mathrm{a}}$ were obtained as described by Lindhout et al. (18). Factor VIII was prepared according to Vehar and Davie (19) with the modifications by van Dieijen et al. (20). Factor IX was prepared according to Fujikawa et al. (21) and activated by incubation with purified factor $\mathrm{XI}_{\mathrm{a}}(22)$.

The breakdown constants of endogenous thrombin and the thrombin generation curves were obtained as described in Hemker et al. (8), $\mathrm{k}$ is the overall breakdown constant, $k_{2}$ is defined as the $\alpha_{2}$-macroglobulin dependent breakdown constant and $k_{1}$ is the remaining part, i.e. largely AT III dependent (8).

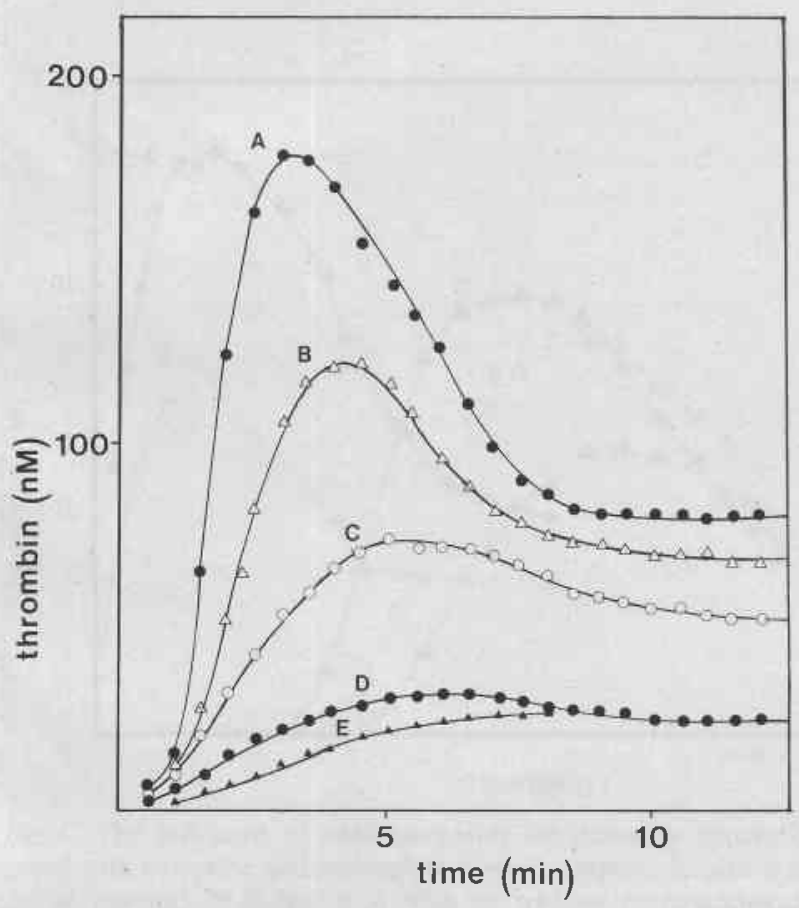

Fig. 1 The influence of pentasaccharide on thrombin generation in the extrinsic system. Reaction mixture: normal plasma $240 \mu \mathrm{l}$, buffer A containing heparin $60 \mu \mathrm{l}$, thromboplastin diluted $1: 40$ in $\mathrm{CaCl}_{2} 0.1 \mathrm{M}$ : $60 \mu$. A. Control. B. $0.05 \mu \mathrm{g} / \mathrm{ml}$ pentasaccharide. C. $0.1 \mu \mathrm{g} / \mathrm{ml}$ pentasaccharide. D. $0.3 \mu \mathrm{g} / \mathrm{ml}$ pentasaccharide, E. $0.6 \mu \mathrm{g} / \mathrm{ml}$ pentasaccharide

\section{Experimental}

The pentasaccharide at concentrations of up to $10 \mu \mathrm{g} / \mathrm{ml}$ had no influence on the inactivation of endogenous thrombin in normal plasma. The inactivation constant $\mathrm{k}\left(=\mathrm{k}_{1}+\mathrm{k}_{2}\right)$ was $1.187 \pm 0.024(\mathrm{n}=10)$ at $5 \mu \mathrm{g} / \mathrm{ml}$ pentasaccharide against $1.179 \pm 0.015(\mathrm{n}=20)$ for control plasma.

When $\mathrm{k}_{2}$, the reaction constant of thrombin and $\alpha_{2}$-macroglobulin was determined it appeared that, like with standard heparin (10), it was not influenced by the presence of pentasaccharide $\mathrm{k}_{2}=0.246 \pm 0.008(\mathrm{n}=8$, S.E. M.) compared to the control $k_{2}=0.253 \pm 0.005$ ( $\mathrm{n}=20$ S.E.M.).

In Figs. 1 and 2 the influence of pentasaccharide on thrombin generation in plasma is shown. There is an evident, dose dependent inhibition, both in the intrinsic and extrinsic systems. Because thrombin decay is not influenced by the pentasaccharide this inhibition cannot be attributed to thrombin scavenging but must be attributed to the inhibition of prothrombinase or to a decreased prothrombinase generation. Either factor $\mathrm{X}_{\mathrm{a}}$ is scavenged or its formation is inhibited.

In the course of these experiments it appeared that pentasaccharide is adsorbed by kaolin. Therefore the usual concentration of kaolin $(0.25 \mathrm{mg} /$ $\mathrm{ml}$ ) used for triggering the intrinsic system was decreased tenfold. With this amount of kaolin, contact activation appeared to be triggered to the same extend as with the higher concentration but pentasaccharide adsorption is hardly apparent anymore.

From Fig. 3 it appears that there is only a minor degree of inhibition when thrombin formation is triggered by a mixture of factors $X_{a}$ and $V_{a}$ and phospholipid in concentrations that ensure that the large majority of factor $\mathrm{X}_{\mathrm{a}}$ molecules is bound in prothrombinase complex. If thrombin formation is triggered by factor $\mathrm{X}_{\mathrm{a}}$ and phospholipid alone the inhibition is much more outspoken. At intermediate factor $V_{a}$ concentrations the inhibition appeared to be dependent upon the amount of factor $V_{a}$ present (results not shown). In Fig. 4 it is seen that the inhibition exerted by pentasaccharide persists when thrombin formation is triggered by the complete factor $\mathrm{X}$ activating complex or by factor $\mathrm{IX}_{\mathrm{a}}$ and phospholipid but without factor VIII $_{\mathrm{a}}$. If thrombin formation is triggered by factor $\mathrm{IX}_{\mathrm{a}}$ and phospholipid there is an appreciable lagtime that is dose dependently prolonged by pentasaccharide.

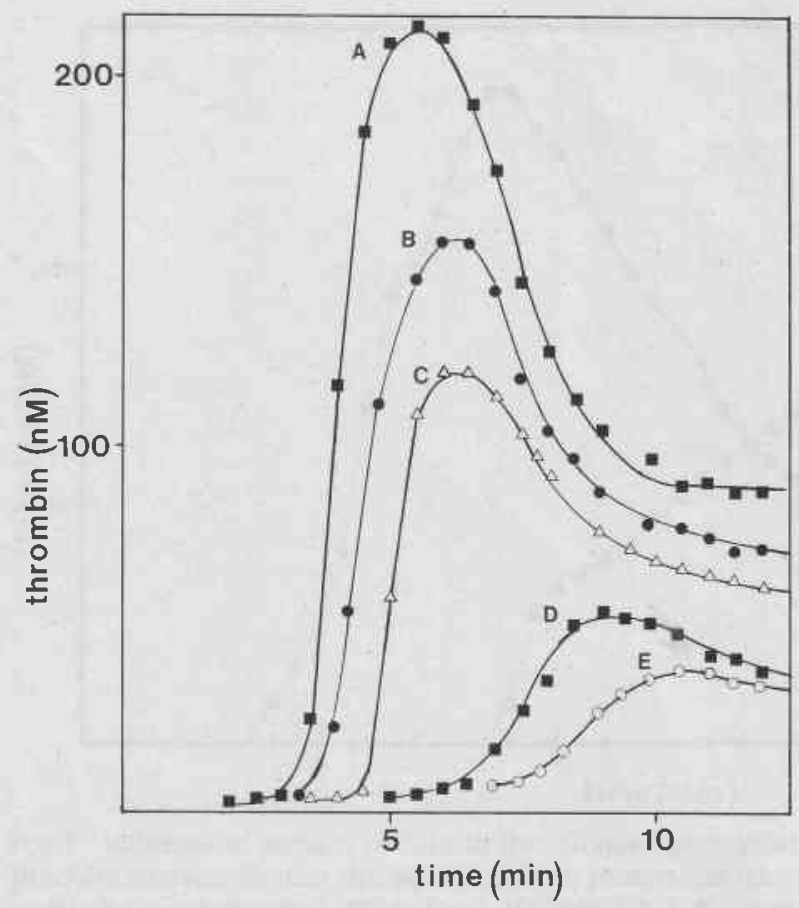

H:. - lihe influence of pentasaccharide on thrombin generation in the intrinsic system. Reaction mixture: normal plasma $240 \mu \mathrm{l}$, buffer $\mathrm{A}$ containing: heparin, koalin $(0.025 \mathrm{mg} / \mathrm{ml})$ and phospholipid $(1 \mu \mathrm{M}) 60 \mu \mathrm{l}$, $\mathrm{CaCl}_{2} 0.1 \mathrm{M}$ : $60 \mu \mathrm{l}$. A. Control. B. $0.05 \mu \mathrm{g} / \mathrm{ml}$ pentasaccharide. C. $0.1 \mu \mathrm{g} / \mathrm{ml}$ pentasaccharide. D. $0.3 \mu \mathrm{g} / \mathrm{ml}$ pentasaccharide. E. $0.6 \mu \mathrm{g} / \mathrm{ml}$ pentasaccharide 


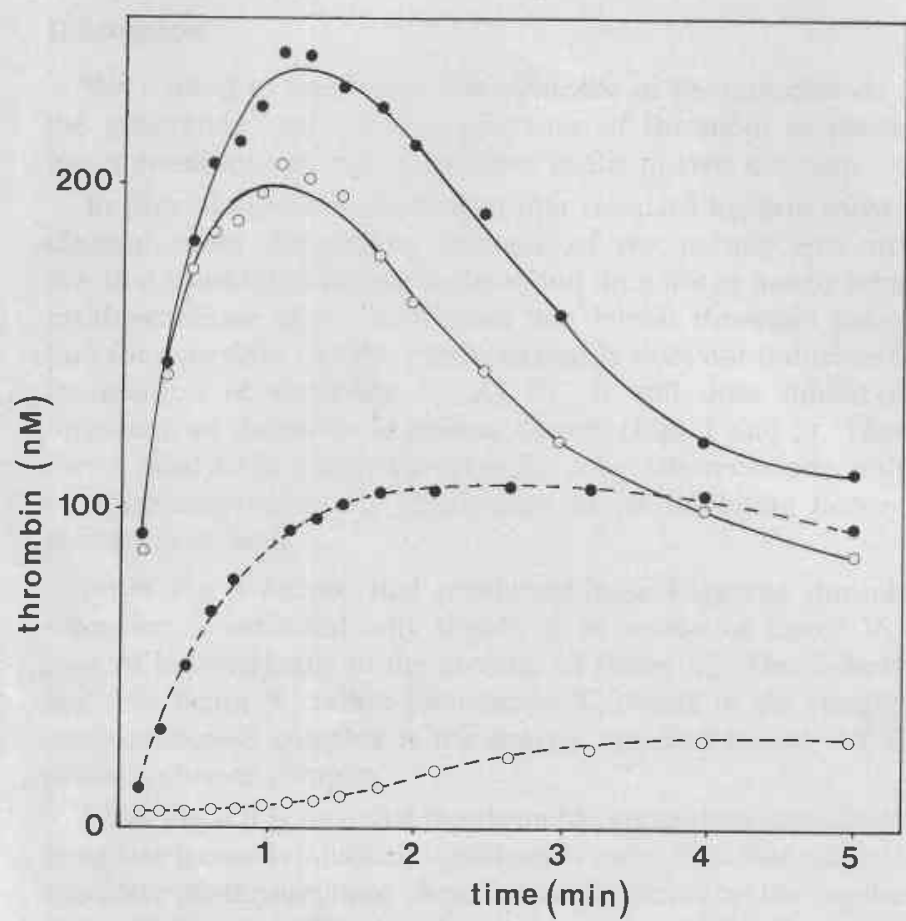

Fig. 3 The influence of pentasaccharide on thrombin formation triggered with complete and incomplete prothrombinase. Reaction mixture: $240 \mu \mathrm{l}$ plasma, $30 \mu \mathrm{l}$ buffer A with or without pentasaccharide, $30 \mu \mathrm{l}$ prothrombinase, $60 \mu \mathrm{l} 0.1 \mathrm{M} \mathrm{CaCl}$. Complete prothrombinase: $5 \mathrm{mM} \mathrm{CaCl}$, $0.1 \mathrm{nM}$ factor $\mathrm{X}_{\mathrm{a}}, 10 \mathrm{nM}$ factor $\mathrm{V}_{\mathrm{a}}, 1 \mu \mathrm{M}$ phospholipid. Incomplete prothrombinase: $5 \mathrm{mM} \mathrm{CaCl}, 0.1 \mathrm{nM}$ factor $\mathrm{X}_{\mathrm{a}}, 1 \mu \mathrm{M}$ phospholipid. - complete prothrombinase; control. $\bigcirc \bigcirc$ complete prothrombinase; $1.2 \mu \mathrm{g} / \mathrm{ml}$ pentasaccharide. $-{ }_{-}$incomplete prothrombinase; control. $\mathrm{O}----\mathrm{O}$ incomplete prothrombinase; $1.2 \mu \mathrm{g} / \mathrm{ml}$ pentasaccharide

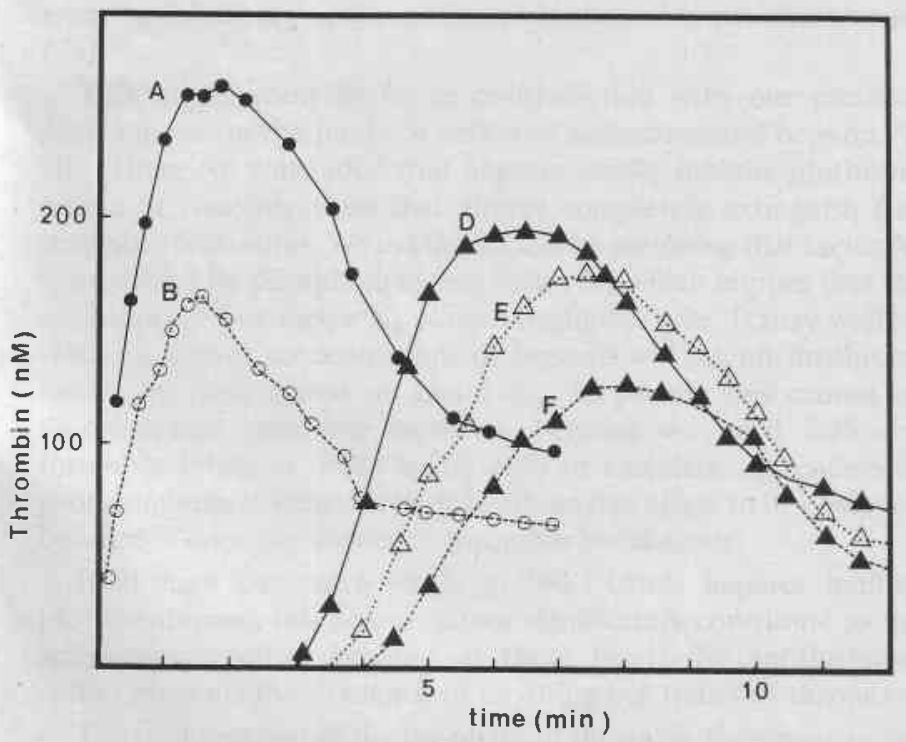

Fig. 4 The influence of pentasaccharide on thrombin generation triggered with complete and incomplete tenase complex. Reaction mixture: $240 \mu \mathrm{l}$ plasma, $30 \mu \mathrm{l}$ buffer A with or without pentasaccharide $30 \mu \mathrm{l}$ tenase, $60 \mu \mathrm{l} 0.1 \mathrm{M} \mathrm{CaCl}_{2}$. Complete tenase: $5 \mathrm{mM} \mathrm{CaCl}_{2}, 10 \mathrm{nM}$ factor $\mathrm{IX}_{\mathrm{a}}, 5 \mathrm{U} / \mathrm{ml}$ factor VIII, $2 \mathrm{nM}$ factor $\mathrm{II}_{\mathrm{a}}, 1 \mu \mathrm{M}$ phospholipid. Incomplete tenase: $5 \mathrm{mM} \mathrm{CaCl}_{2}, 10 \mathrm{nM}$ factor $\mathrm{IX}_{\mathrm{a}}, 1 \mu \mathrm{M}$ phospholipid. A. Control; complete tenase. B. Complete tenase; $0.200 \mu \mathrm{g} / \mathrm{ml}$ pentasaccharide. D. Control; incomplete tenase. E. Incomplete tenase; $0.050 \mu \mathrm{g} / \mathrm{ml}$ pentasaccharide. F. Incomplete tenase; $0.200 \mu \mathrm{g} / \mathrm{ml}$ pentasaccharide
Table 1 IC 50 values for the inhibition of prothrombinase generation by pentasaccharide and heparin in platelet free plasma

\begin{tabular}{lcrc}
\hline & $\begin{array}{c}\text { Pentasaccharide } \\
\mu \mathrm{g} / \mathrm{ml}\end{array}$ & $\begin{array}{c}\text { Heparin } \\
\mu \mathrm{g} / \mathrm{ml}\end{array}$ & \multicolumn{1}{c}{$\mathrm{U} / \mathrm{ml}$} \\
\hline Intrinsic system & 0.1 & 0.15 & 0.10 \\
Extrinsic system & 0.1 & $>0.15$ & $>0.10$ \\
Complete prothrombinase & $>1.5$ & $>0.15$ & $>0.10$ \\
Factor $\mathrm{X}_{\mathrm{a}}$-phospholipid & 0.2 & 0.12 & 0.08 \\
Complete tenase & 0.2 & 0.15 & 0.10 \\
Factor $\mathrm{IX}_{\mathrm{a}}$-phospholipid & 0.2 & $<0.008$ & $<0.005$ \\
\hline
\end{tabular}

In Table 1 we summarized the effects of pentasaccharide in terms of the concentrations that would cause $50 \%$ inhibition of the peak of prothrombinase activity in normal plasma. Because pentasaccharide does not influence thrombin breakdown its effect on prothrombinase can be read directly from its effect on thrombin generation. In Table 1 the $\mathrm{IC}_{50}$ values of the inhibition of prothrombinase generation by heparin, obtained from the data in Béguin et al. (10), are added for comparison. The latter data are computed from thrombin generation curves and the corresponding breakdown constants.

Next we determined the effect of the pentasaccharide in platelet rich plasma. Here important differences with unfractionated heparin become apparent. Unfractionated heparin will retard the burst of thrombin formation but will not influence the peak amount of thrombin formed. The reason being that platelets, activated by trace amounts of thrombin generated during the lagtime simultaneously make available procoagulant phospholipids and heparin neutralizing platelet factor 4 . Once the platelets are activated thrombin activation is explosively enhanced by the phospholipids that appear but also the heparin is virtually removed from the system $(9,11)$.

Pentasaccharide does prolong the lagtime, as is to be expected because it diminishes the amount of thrombin available for triggering the platelets. Contrary to unfractionated heparin it also markedly inhibits the peak of thrombin formation (Fig. 5).

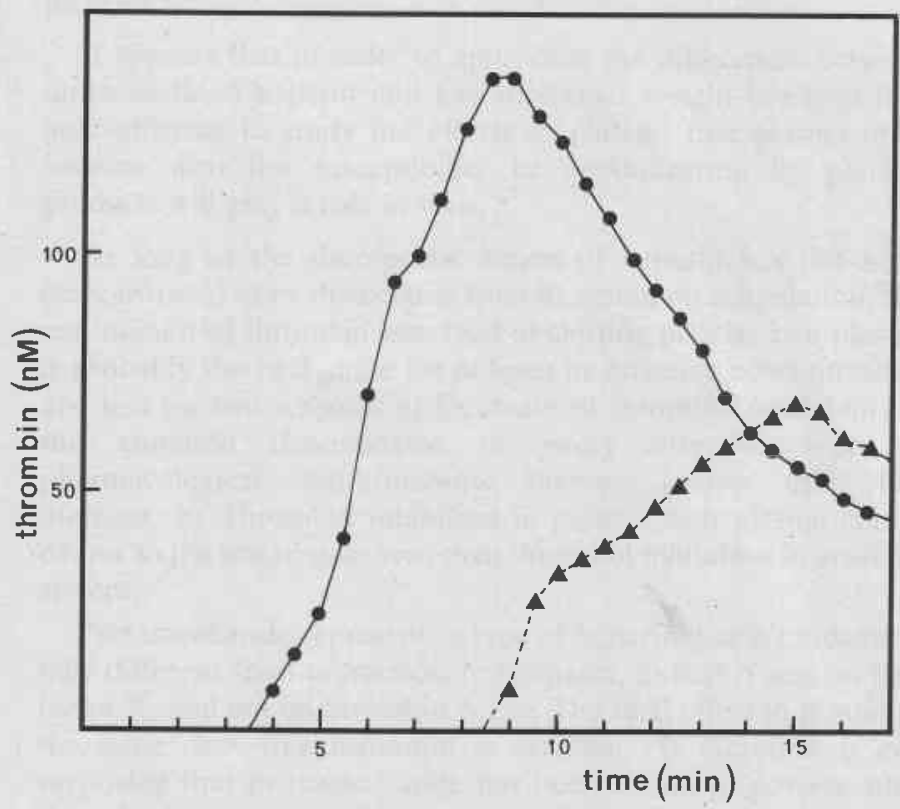

Fig. 5 Influence of pentasaccharide on the thrombin generation in PRP. Reaction mixture: Platelet rich plasma: $240 \mu \mathrm{l}$; pentasaccharide or buffer A: $60 \mu \mathrm{l}$; thromboplastin 1:400 in $\mathrm{CaCl}_{2} 100 \mathrm{mM}: 60 \mu \mathrm{l}$. $\longrightarrow$ control, $\Delta----\Delta$ pentasaccharide $1.2 \mu \mathrm{g} / \mathrm{ml}$ 


\section{Discussion}

We wanted to investigate the influence of pentasaccharide on the generation and the disappearance of thrombin in plasma, under conditions as near as possible to the in vivo situation.

In previous articles we showed that standard heparin causes a clearcut, dose dependent, increase of the pseudo first-order reaction constant of thrombin decay but does not or hardly inhibit prothrombinase at concentrations that inhibit thrombin generation for over $85 \%(9,10)$. Pentasaccharide does not influence the inactivation of thrombin by AT III. It still does inhibit the formation of thrombin in plasma though (Figs. 1 and 2). Therefore it must act at a higher level in the coagulation cascade, either by increasing factor $\mathrm{X}_{\mathrm{a}}$ inactivation or by inhibiting factor $\mathrm{X}$ activation or both.

From Fig. 3 we see that prothrombinase triggered thrombin formation is inhibited only slightly if an excess of factor $V_{a}$ is present but markedly in the absence of factor $V_{a}$. This indicates that free factor $X_{a}$ rather than factor $X_{a}$ bound in the complete prothrombinase complex is the species attacked by the AT IIIpentasaccharide complex.

From Fig. 4 it is seen that the thrombin generation provoked by complete tenase is inhibited significantly more than that caused by complete prothrombinase. Apart from the effect on the lagphase the inhibition of thrombin formation triggered by factor $I_{\mathrm{a}^{-}}$ phospholipid and by complete tenase (factors $\mathrm{IX}_{\mathrm{a}}$ and $\mathrm{VIII}_{\mathrm{a}}$ and phospholipid) are comparable (Fig. 4, Table 1). This indicates that factor $\mathrm{IX}_{\mathrm{a}}$ needs not be protected by factor $\mathrm{VIII}_{\mathrm{a}}$ probably because factor $\mathrm{IX}_{\mathrm{a}}$ is not subject to important AT III-pentasaccharide induced inactivation.

The fact that thrombin generation induced by complete or incomplete tenase and incomplete prothrombinase is markedly inhibited whereas that induced by complete prothrombinase is not, indicates that the product of tenase, i. e. factor $X_{a}$, goes through a free stage and is not immediately bound to factor $V_{a}$ and phospholipid, after its production. It also is in agreement with the observation of Barrowcliffe that pentasaccharide will hardly exert an inhibitory action on factor $\mathrm{X}_{\mathrm{a}}$ bound in prothrombinase (23).

This might seem to be in contradiction with our previous propositions on the mode of action of unfractionated heparin (9; 10 ). There we concluded that heparin hardly inhibits prothrombinase at concentrations that almost completely extinguish free thrombin formation. We explained this by assuming that factor $\mathrm{X}_{\mathrm{a}}$ is protected by phospholipid and factor $\mathrm{V}_{\mathrm{a}}$ which implies that the inhibition of free factor $\mathrm{X}_{\mathrm{a}}$ plays a negligible role. It may well be that still higher concentrations of heparin will inhibit prothrombinase by their action on factor $\mathrm{X}_{\mathrm{a}}$. In plasma this cannot be demonstrated with our methods, because we need sufficient thrombin levels in order to be able to calculate the course of prothrombinase. Pentasaccharide allows this effect to be observed because it does not influence thrombin breakdown.

If at high concentration (e.g. $>0.1 \mathrm{U} / \mathrm{ml}$ ) heparin inhibits prothrombinase, this action cannot significantly contribute to the anticoagulant effect because at these levels the antithrombin action prevents the existence of anything but traces of thrombin.

The prolongation of the lag phase of thrombin formation in the intrinsic system (Fig. 2) finds an unforced explanation in the fact that low ambient concentrations of thrombin during the lagphase will retard feedback activation of factor VIII. This explanation is the same as that forwarded for the prolongation of the lagphase by heparin $(10)$, be it that the cause of the low thrombin levels during the lagtime in the case of pentasaccharide is low prothrombin activation whereas with heparin it is increased thrombin breakdown.
Heparin will inhibit intrinsic prothrombin activation to a greater extent than the extrinsic one. This is attributed to the fact that factor $\mathrm{IX}_{\mathrm{a}}$, in the absence of factor $\mathrm{VIII}_{\mathrm{a}}$, i. e. during the lag time, is subject to heparin-AT III dependent decay $(9,10)$. Pentasaccharide shows approximately the same inhibition in the intrinsic and in the extrinsic system (Table 1), again indicating that contrary to heparin, pentasaccharide does not significantly enhance the inactivation of factor $\mathrm{IX}_{\mathrm{a}}$ in plasma. This is corroborated by the observation that it is possible to provoke notable thrombin formation by factor IX $_{\mathrm{a}}$-phospholipid in the absence of factor VIII $_{\mathrm{a}}$, whereas with heparin this is impossible (Fig. 4, ref. 10).

It has been shown that trace amounts of thromboplastin provoke the generation of traces of thrombin that will activate platelets in platelet rich plasma. The time necessary for this process is the lagtime of platelet activation. Once the platelets are activated they will make phospholipid and factor $V$ available and explosive thrombin formation ensues. During the lagtime the system may be conceived as inactive platelets suspended in platelet poor plasma $(9,11)$.

Pentasaccharide, like classical heparin, will restrict the availability of trace amounts of thrombin during the lagphase, not by thrombin scavenging but by inhibition of prothrombinase formation. The prolongating effect on the lagtime is the same however. Unlike unfractionated heparin, of which up to $0.4 \mathrm{U} / \mathrm{ml}$ $(\sim 2.1 \mu \mathrm{g} / \mathrm{ml})$ are completely neutralized by activated platelets $(9,11)$, pentasaccharide appears to maintain part of its activity in the presence of activated platelets because it does inhibit thrombin generation in platelet rich plasma, be it less than in platelet free plasma (Fig. 1,2 and 5). The explanation of this phenomenon is either that the affinity of neutralizing protein from platelets is less for pentasaccharide than for heparin or that the higher molar concentration of $1.2 \mu \mathrm{g} / \mathrm{ml}$ of pentasaccharide $(\sim 0.7 \mu \mathrm{M})$ compared to that of $0.4 \mathrm{U} / \mathrm{ml}$ of heparin $(\sim 0.15 \mu \mathrm{M})$ represents a molar excess that exceeds the neutralizing capacity of the released proteins.

It appears that in order to appreciate the differences between unfractionated heparin and low molecular weight heparins it is not sufficient to study the effects in platelet free plasma only, because also the susceptibility to neutralization by platelet products will play a role in vivo.

As long as the therapeutic action of heparin has not been demonstrated to be dissociable from its action on coagulation, the net amount of thrombin observed in clotting platelet rich plasma is probably the best guide for judging its effective concentration, and this for two reasons: a) Decrease of thrombin availability is the common denominator of every effective type of pharmacological antithrombotic therapy known until this moment. b) Thrombin inhibition in platelet rich plasma comes nearer to the situation in vivo than thrombin inhibition in artificial systems.

Pentasaccharide represents a type of heparin that is fundamentally different from unfractionated heparin, in that it acts on free factor $\mathrm{X}_{\mathrm{a}}$ and not on thrombin decay. The final effect in plasma is the same: less free thrombin is available. It therefore is not surprising that pentasaccharide has been shown to possess antithrombotic action in animal experiments (24).

\section{Acknowledgements}

We thank Dr. Theo Lindhout and Dr. R. Wagenvoord for fruitful discussions and purified clotting factors, Paul Devilée for expert technical assistance and Trees Camphuisen-Engel for preparing the manuscript. Financial support has been obtained from the Dutch Thrombosis Foundation and La Fondation de France. 


\section{References}

1 Barrowcliffe T W, Johnson E A, Eggleton C A, Kemball-Cook G, Thomas D P. Anticoagulant activities of high and low molecular weight heparin fractions. Br J Haematol 1979; 41: 573-83.

2 Andersson L O, Barrowcliffe T W, Holmer E, Johnson E A, Söderstrom G. Molecular weight dependency of the heparin potentiated inhibition of thrombin and activated factor X. Effect of heparin neutralization in plasma. Thromb Res 1979; 15: 531-41.

3 Holmer E, Kurachi K, Söderstrom G. The molecular-weight heparin dependence of the rate-enhancing effect of heparin on the inhibition of thrombin, factor $X_{a}$, factor $\mathrm{IX}_{\mathrm{a}}$, factor $\mathrm{XI}_{\mathrm{a}}$, factor $\mathrm{XII}_{\mathrm{a}}$ and kallikrein by antithrombin. Biochem J 1981; 193; 395-400.

4 Björk I, Lindahl U. Mechanism of the anticoagulant action of heparin. Mol Cell Biochem 1982; 48: 161-2.

5 Lane A, Denton J, Flynn A M, Thunberg L, Lindahl U. Anticoagulant activities of heparin oligosaccharides and their neutralization by platelet factor 4. Biochem J 1984; 218: 725-32.

6 Casu B, Oreste P, Torri G, Zoppetti G, Choay J. Lormeau J C, Petitou M, Sinay P. The structure of heparin oligosaccharide fragments with high anti-(factor $X_{a}$ ) activity containing the minimal antithrombin III-binding sequence. Biochem J 1981; 197: 599-609.

7 Choay J, Petitou M, Lormeau J C, Sinay P, Casu B J, Gatti G. Structure-activity of relationship in heparin: a synthetic pentasaccharide with high affinity for antithrombin III and eliciting high antifactor $X_{a}$ activity. Biochem Biophys Res Comm 1983; 116: 492-9.

8 Hemker H C, Willems G M, Béguin S. A computer assisted method to obtain the prothrombin activation velocity in whole plasma independent of thrombin decay processes. Thromb Haemostas 1986; 56: 9-17.

9 Hemker H C. The mode of action of heparin in plasma. XIth Congress Thrombosis Haemostasis, Brussels. Verstraete M, Vermylen J, Lijnen H R, Arnout J (eds). Leuven University Press, Leuven 1987; pp 17-36.

10 Béguin S, Lindhout T, Hemker $\mathrm{H} \mathrm{C}$. The mode of action of heparin in plasma. Thromb Haemostas 1988; 60: 457-62.

11 Béguin S, Lindhout T, Hemker H C. The effect of trace amounts of tissue factor on thrombin generation in platelet rich plasma, its inhibition by heparin. Thromb Haemostas 1989; 61: 25-9.

12 Hendriks H, Lindhout T, Mertens K, Engels W, Hemker H C. Activation of human prothrombin by stoichiometric levels of staphylocoagulase. J Biol Chem 1983; 258: 3637-44.
13 Rosing J, Tans G, Govers-Riemslag J W P, Zwaal R F A, Hemker H C. The role of phospholipids and factor $\mathrm{V}_{\mathrm{a}}$ in the prothrombinase complex. J Biol Chem 1986; 255: 274-83.

14 Owren P A, Aas K. The control dicoumarol therapy and the quantitative determination of prothrombin and proconvertin. Scand J Clin Lab Invest 1951; 3: 201-18.

15 Petitou M, Duchaussoy P, Lederman I, Choay J, Jacquinet J-C, Sinai P, Torri G. Synthesis of heparin fragments: A methyl-pentaoside with high affinity for antithrombin III. Carbohydrate Res 1987; 167: 67-75.

$16 \mathrm{Ma}$ Xi, Béguin S, Hemker H C. The importance of factor IX activation in thromboplastin-dependent coagulation (the Josso pathway) in plasma. Haemostasis 1989; accepted for publication.

17 Pletcher C H, Nelsestuen G I. The rate determining step of the heparin-catalyzed antithrombin-thrombin reaction is independent of thrombin. J Biol Chem 1982; 257: 5342-5.

18 Lindhout T, Govers-Riemslag J W P, van der Waart P, Hemker H C, Rosing $\mathrm{J}$. Factor $\mathrm{V}_{\mathrm{a}}$, factor $\mathrm{X}_{\mathrm{a}}$ interaction. Effects of phospholipid vesicles of varying composition. Biochemistry 1982; 21: 5494-502.

19 Vehar G A, Davie E W. Preparation and properties of bovine factor VIII. Biochemistry 1980; 19: 401-10.

20 van Dieijen G, van Rijn J L M L, Govers-Riemslag J W P, Hemker H $\mathrm{C}$, Rosing J. Assembly of the intrinsic factor $\mathrm{X}$ activating complex; interactions between factor $\mathrm{IX}_{\mathrm{a}}$, factor $\mathrm{VIII}_{\mathrm{a}}$ and phospholipid. Thromb Haemostas 1985; 53: 396-400.

21 Fujikawa K, Thompson A R, Legaz M E, Meyer R G, Davie E W. Isolation and characterization of bovine factor IX (Christmas Factor). Biochemistry 1973; 12: 4938-45.

22 Fujikawa K, Legaz M E, Kato H, Davie E W. The mechanism of activation of bovine IX (Christmas factor) by bovine factor $\mathrm{XI}_{\mathrm{a}}$ (activated plasma thromboplastin antecedent). Biochemistry 1974; 13: 4508-16.

23 Barrowcliffe T W, Havercroft S J, Kemball-Cook G, Lindahl U. The effect of $\mathrm{Ca}^{2+}$, phospholipid and factor $\mathrm{V}$ on the anti-(factor $\mathrm{X}_{\mathrm{a}}$ ) activity of heparin and its high oligosaccharides. Biochem $\mathrm{J} 1987 ; 243$ : $31-7$.

24 Walenga J M, Fareed J, Petitou M, Samama M, Lormeau J C, Choay $\mathrm{J}$. Intravenous antithrombotic activity of a synthetic heparin polysaccharide in a human serum induced stasis thrombosis model. Thromb Res 1986; 43: 243-8.

Received November 22, 1988 Accepted after revision February 22, 1989 